\title{
EDUKACJA W PAŃSTWACH BRICS
}

\section{Abstract \\ Education in the BRICS Countries}

Financing and creation of education system are considered a public sector's duty. In the long term, efficiency in the realization of these tasks influences the condition of the country's labor market. Finally, it is one of the factors determining the competitive position of the country.

The author touched upon the problem of the economic growth in the BRIC countries at the end of the $20^{\text {th }}$ and at the beginning of the $21^{\text {st }}$ century. Identification of the reasons for growth was an element of a study conducted on a group of 32 experts in the summer 2015. The article focuses on the influence of education on the countries' development. The final aim is to analyse the countries' involvement in education, changes in the last decades and their impact on development - mostly on the basis of external evaluation, e.g. reports on the competitive positions of the economies.

As a result of the analysis, the author deduced that the increase in financing education is convergent with the higher level of development. Moreover, it was confirmed that the level of education in a society is an important factor determining the competitive potential of an economy.

Keywords: Brazil, Russian Federation, India, China, South Africa, competitiveness

\section{Streszczenie}

Oświata, jej finansowanie i modelowanie są uznawane za obowiązki sfery publicznej. Skuteczność realizacji zadań z tego zakresu w długim okresie przekłada się na kondycję rynku pracy w danej gospodarce. Ostatecznie, jest to jeden z czynników decydujących o pozycji konkurencyjnej danego państwa.

W artykule podjęto problem wzrostu gospodarek państw BRICS w ostatnich dekadach XX i na początku XXI wieku. Wskazanie przyczyn tego wzrostu było elementem badania przeprowadzonego latem 2015 roku na grupie 32 ekspertów. Przyjęty w artykule punkt widzenia dotyczy wpływu edukacji na rozwój tych państw. Ostatecznym celem jest określenie zaangażowania państw w sferę edukacyjną, zmian, jakie zaszły w ostatnich dziesięcioleciach w tym obszarze oraz ich wpływu na rozwój tych państw - przede wszystkim przez pryzmat ocen zewnętrznych, m.in. raportów dotyczących pozycji globalnej gospodarek.

W wyniku przeprowadzonej analizy stwierdzono, iż wzrost nakładów na edukację jest zbieżny z rozwojem danego kraju. Poza tym potwierdzono, że poziom wyedukowania spo- 
łeczeństwa jest ważnym czynnikiem określającym potencjał konkurencyjny danej gospodarki.

Słowa kluczowe: Brazylia, Rosja, Indie, Chiny, RPA, konkurencyjność

\section{Wstęp}

Edukacja jest jednym z elementów świadczących o rozwoju państwa [Grodzicki, 2000, s. 22]. Im wyższy poziom rozwoju, tym wyższe wydatki na oświatę (formalną edukację) w porównaniu do innych kategorii budżetowych [OECD, Education..., 2015]. Państwa rozwinięte charakteryzuje niski poziom analfabetyzmu, a znaczny odsetek osób z wykształceniem wyższym [UNESCO, International..., b.d.]. Już o jeden procent wyższy poziom alfabetyzacji od średniej międzynarodowej przekłada się na wyższą wydajność siły roboczej $(2,5 \%)$ i wyższy PKB na jednego mieszkańca (1,5\%) [Stańko, 2009, s. 85]. Edukacja jest więc istotnym elementem rozwoju społeczno-gospodarczego.

Państwa BRICS (Brazylia, Rosja, Indie, Chiny, RPA) uznawane są za gospodarki rozwijające się [Liberska, 2013, s. 195-197]. W ciągu ostatnich kilku dekad dokonały olbrzymich przeobrażeń. Edukacja, ze względu na swoją długofalowość i perspektywiczność, jest jednym z elementów odpowiedzialnych za potencjał konkurencyjny tych gospodarek.

W ramach rozważań przyjęto, iż inwestycje w edukację w BRICS pozwoliły utrzymać wzrost gospodarczy na początku XXI wieku i doprowadziły do przyspieszenia ich rozwoju. Edukacja kształtuje kapitał ludzki. Sprawny system oświaty pozwala na podniesienie początkowej wartości siły roboczej. Założono więc, że wzrost wielkości nakładów na oświatę przełożył się na poprawę konkurencyjności takiej gospodarki. Lepiej wyedukowany kapitał ludzki zachęca do podejmowania działalności gospodarczej w takim kraju. To ostatecznie przekłada się na wyższy poziom produktu krajowego. Wpływ mają na to długotrwałe utrzymywanie jakości i dopasowanie systemu oświaty. Utrzymanie dalszego wzrostu państw BRICS wymaga stałego finansowania szkolnictwa zawodowego i rozwijania szkolnictwa wyższego, w tym pozycjonowania uniwersytetów na arenie międzynarodowej. Silne jednostki naukowe umożliwiają pozyskanie najlepszych studentów i naukowców, co prowadzi do poprawy gospodarczego wizerunku danego państwa.

Celem artykułu jest określenie zaangażowania państw w edukację, przedstawienie zmian, jakie zaszły w ostatnich dziesięcioleciach w obszarze oświaty, szkolnictwa wyższego i finansowania nauki oraz ich wpływu na rozwój tych państw - przede wszystkim przez pryzmat ocen zewnętrznych, m.in. raportów dotyczących pozycji globalnej gospodarek.

Pierwsza część artykułu została poświęcona analizie systemów oświaty BRICS (ich przemian, charakteru i warunków) na bazie informacji dostępnych na stronach ministerstw poszczególnych państw, a także danych dotyczących finansowania oświaty w podziale na poziomy kształcenia. Następnie skupiono się na kwestiach 
związanych ze szkolnictwem wyższym, jako często wymienianym elementem konkurencyjności gospodarek szczególnie ważnym dla międzynarodowych korporacji. W kolejnej części zestawiono z sobą wybrane kategorie raportów konkurencyjności Światowego Forum Ekonomicznego. W ten sposób wnioskowano odnośnie do zależności między edukacją, rozwojem a konkurencyjnością państw.

Poznanie przyczyn rozwoju jednych, a stagnacji innych gospodarek może umożliwić skuteczniejsze prowadzenie polityk władz publicznych, z korzyścią dla obecnych i przyszłych pokoleń. Na początku rozważań warto zająć się edukacją w państwach BRICS i przyjrzeć się funkcjonującym tam systemom oświaty.

\section{Systemy oświaty w państwach BRICS}

System oświaty w wielu państwach jest obsługiwany przez podmioty publiczne i prywatne. Dotychczas nie zaobserwowano korelacji między poziomem rozwoju a proporcjami publicznych i prywatnych instytucji edukacyjnych. Gwarantowana do pewnego wieku bądź poziomu kształcenia edukacja jest cechą państwa rozwiniętego. Jest to znaczny koszt, ponieważ przez ten okres ludzie nie wytwarzają produktu krajowego, natomiast pozostała część społeczeństwa ich utrzymuje. Kraje uboższe oferują swoim obywatelom mocno ograniczoną edukację eliminującą analfabetyzm, umożliwiającą podjęcie pracy. Na niższych poziomach rozwoju kraju nie stanowi to problemu. Dostosowywanie oświaty (poziomu, zakresu i dostępności edukacji) jest kosztowne, dlatego powinno być skorelowane $\mathrm{z}$ rozwojem danego kraju. BRICS różnią się pod względem jakości kształcenia. Warto więc przybliżyć rozwiązania systemowe występujące w tych krajach.

W Brazylii za przygotowanie i finansowanie programów edukacyjnych odpowiada Ministerstwo Edukacji Narodowej [Ministério da...]. Ich wdrożeniem zajmują się władze lokalne i regionalne. Celem programów jest nie tylko edukowanie, ale również redukcja problemów społeczno-ekonomicznych [MEC, b.d.].

Formalna edukacja w Brazylii została podzielona na cztery etapy. Bezwarunkowo bezpłatna i obowiązkowa skierowana jest do dzieci w wieku 6-14 lat, zgodnie z informacjami przedstawionymi w tabeli (Tabela 1). Wykształcenie średnie jest obowiązkowe dla tych, którzy chcą kontynuować edukację na studiach wyższych [MEC, b.d.]. Szkolnictwo wyższe jest bezpłatne na uczelniach publicznych. Studia dzielą się na dwie części: licencjat i magisterium. Uniwersytety wspierają badania naukowe i często korzystają z finansowania zewnętrznego [Bittar, 2000, s. 5]. Studia kończą się obroną pracy magisterskiej. Tytuł magistra umożliwia podjęcie dodatkowego kształcenia na studiach doktoranckich, które kończą się publiczną obroną. W Brazylii uniwersytety są objęte nadzorem federalnych Komisji ds. Edukacji, Nauki i Technologii w zakresie jakości kształcenia [World data on education, b.d.].

Największym problemem brazylijskiego szkolnictwa jest stosunkowo niska dostępność szkół, szczególnie na wsi. Drugim - znaczne zróżnicowanie regionalne szkół pod względem infrastruktury i jakości kształcenia. 
W Rosji za kwestie związane z edukacją odpowiedzialne jest Ministerstwo Nauki i Edukacji [Ministry of Education...]. Władze regionalne wdrażają rozwiązania w ramach obowiązującego zestawu ustaw federalnych. Edukacja w Rosji jest obowiązkowa do 17. roku życia. Dzieci są przyjmowane do pierwszej klasy w wieku 6-7 lat. Od piątej klasy przedmioty prowadzone są przez nauczycieli przedmiotowych. Po dziewięciu latach nauki uczeń decyduje, czy kończy dwa kolejne lata w szkole ogólnej czy zawodowej.

Od 2003 roku testy kończące szkołę średnią są jednolite, a ich wyniki obowiązujące jako podstawa do rekrutacji na studia. W Rosji ponad połowa ludności ukończyła studia. Liczba studentów stale rośnie, również tych z zagranicy. W 2010 r. stanowili oni ponad 6\% ogółu [Ministry of Education...]. Unowocześnianie gospodarki, a przede wszystkim przemysłu i usług, powoduje, że zapotrzebowanie na kształcenie wyższe rośnie. Stale wzrasta liczba uczelni prywatnych. Obecnie rosyjskie uczelnie przechodzą konsolidację, co ma poprawić jakość kształcenia i ograniczyć „rozdawnictwo dyplomów” [Czeladko, b.d.].

Od 2007 roku w Rosji obowiązuje system boloński. Po ukończeniu studiów możliwe jest zdobycie jeszcze dwóch tytułów: kandydata nauki i doktora nauki. Oprócz nich występują jeszcze dwa tytuły naukowe (akademickie): docent i profesor.

Edukacja w Rosji nie ustępuje standardom rozwiniętej części świata, co korzystnie wpływa na lokowanie inwestycji zagranicznych [Soboleva, 2011, s. 235-257]. Nauka jest bezpłatna również na studiach (z pewnymi obostrzeniami). Struktura płci w ramach ścieżki edukacyjnej jest zrównoważona (w przeciwieństwie do większości BRICS) poza studiami, na których przeważają kobiety [UNESCO, Education..., b.d.].

Ludność w Rosji jest stosunkowo dobrze wyedukowana, choć nie zawsze profil kształcenia został dopasowany do potrzeb rynku pracy [Fan, Overland, 1999, s. 628-629]. Odpowiednia jakość kształcenia jest zapewniania poprzez zwiększoną uwagę nauczycieli [OECD, Russian Federation..., b.d.]. W 2014 roku „The Economist", oceniając system edukacji w Rosji, umieścił go na 8. miejscu w Europie i 13. na świecie [,The Economist”, b.d.].

W Indiach edukacja dzieci rozpoczyna się w wieku 6 lat. Jest bezpłatna i obowiązkowa do 14. roku życia, co reguluje konstytucja [The Constitution of India..., b.d.]. Nie wyklucza to jednak samodzielnej nauki w domu [Madaan, b.d.]. System szkolnictwa publicznego został uzupełniony przez znaczną liczbę placówek prywatnych (stosunek liczby placówek publicznych do prywatnych wynosi 7:5). W pierwszej dekadzie XXI wieku ok. 50\% dzieci zamieszkujących miasta i ok. $20 \%$ dzieci z obszarów wiejskich uczęszczało do szkół prywatnych. Szkoły prywatne oferują bardziej zróżnicowany program, uzupełniony dodatkowymi zajęciami. Dużym sukcesem w zakresie edukacji jest zwiększenie liczby dzieci uczestniczących w obowiązkowym cyklu kształcenia do poziomu ok. 96\%. Poza tym likwidowana jest różnica między mężczyznami a kobietami, które coraz częściej uczestniczą w edukacji [Velkoff, 1998, s. 4].

Ze względu na powszechne ubóstwo, do edukacji nie przystępuje odpowiednio dużo niepełnoletnich osób. Rząd realizuje wiele programów na rzecz poprawy 
dostępności kształcenia, takich jak np. DERP, uruchomiony w 1994 roku z myślą o uniwersalizacji edukacji podstawowej w Indiach [Purohit, 2014, s. 128-129]. Niestety jakość edukacji pozostaje na niskim poziomie. Przyczyną tego są źle wyedukowane kadry nauczycielskie i ich niedostateczna ilość [Dhawan, b.d.].

Indyjski system szkolnictwa wyższego jest trzecim co do wielkości, po Chinach i USA. Bezpośredni kształt nadaje mu Ministerstwo Szkolnictwa Wyższego [Department of Higher...]. Nadzór nad uniwersytetami sprawuje komisja grantowa. Duże znaczenie ma rozbudowany system kształcenia na odległość. Istotną rolę odgrywają również instytuty techniczne.

Problemem szkolnictwa wyższego jest niedostateczny nadzór nad placówkami: umożliwia się zakładanie szkół, kształcenie i wydawanie dyplomów bez nadzoru [Cheney, 2005, s. 20-21]. Podobnie jak w Rosji, problemem pozostaje korupcja, prowadząca do legalizacji działalności instytucji quasi-naukowych. Pomimo sukcesu, jakim można określić znaczący wzrost liczby osób piśmiennych w Indiach, nadal spora część społeczeństwa kończy edukację na niższych, obowiązkowych poziomach.

Edukacja w Chinach po okresie zamknięcia i licznych eksperymentów za rządów Mao Zedonga wymagała reform. W 1985 roku rozpoczęto proces zmian, które diametralnie odmieniły chińską oświatę. Edukacja stała się ważnym czynnikiem podnoszącym konkurencyjność i świadczącym o rozwoju Chin [Tsang, 1996, s. 425-426].

Ministerstwo Edukacji zajmuje się nadzorem i finansowaniem oświaty w Chinach [Ministry of Education...]. Wszyscy obywatele są objęci obowiązkiem szkolnym w wieku od 6. do 14. roku życia. Uzupełnieniem szkoły podstawowej i gimnazjum są trzyletnie licea, technika i szkoły zawodowe. Najlepsi absolwenci mogą podjąć studia.

Chiny, tak jak Indie, ze względu na znaczny przyrost naturalny mają stosunkowo wysoki udział osób w wieku szkolnym w ogóle społeczeństwa (ok. 19\%). Stąd silny nacisk państwa na rozwijanie infrastruktury edukacyjnej. Celem rządu jest uzyskanie wskaźnika skolaryzacji na poziomie państw rozwiniętych [MOE, b.d.].

Dużym problemem w Chinach pozostaje odległość, jaką dzieci muszą pokonać, aby dotrzeć do szkoły. Rodzice w wielu przypadkach partycypują w kosztach transportu, zakupu podręczników i wyżywienia. Skutecznym rozwiązaniem okazało się tworzenie szkół przy zakładach pracy oraz systemów stypendialnych dla najuboższych [UNESCO, Country Profiles..., b.d.].

Boom przemysłowy pod koniec XX wieku zachęcił do wspierania szkolnictwa zawodowego. Od 1976 do 1996 roku zwiększono odsetek uczniów szkół zawodowych z 5 do 36\%. Pracodawcy, pomimo poprawy stanu szkolnictwa zawodowego, często samodzielnie szkolą absolwentów [Bingman, 2010, s. 27-29].

Szkolnictwo wyższe w Chinach jest stale rozwijane. W ostatnich dwóch dekadach dokonano wielu inwestycji w sferę badawczą, $w$ tym: przeprowadzono realokację szkół wyższych, tworząc z nich regionalne konglomeraty, powiązano wiele uczelni z dużymi przedsiębiorstwami, tworząc zaplecza badawcze, ustandaryzowano naukę, stworzono specjalny fundusz B+R dla najlepszych uczelni. Integracja edukacji wyższej i przemysłu przynosi rezultaty, np. rośnie liczba rejestrowanych 
rocznie patentów [Niewiński, b.d.]. Pomimo sukcesów rodzimych uczelni i ich coraz wyższych pozycji w prestiżowych rankingach zamożniejsi studenci wybierają uczelnie amerykańskie i europejskie [Zhang, 2003, s. 45]. Rośnie również liczba cudzoziemców studiujących w Chinach. Obecnie Chiny zajmują 6. miejsce w liczbie studentów z innych państw [Yang, Gale, 2003, s. 10-11].

Edukacja w RPA jest nadzorowana przez Departament Edukacji Podstawowej [National Department...], który jest odpowiedzialny za szkoły na poziomie podstawowym i średnim, oraz Departament Kształcenia i Szkolnictwa Wyższego - odpowiedzialny za szkoły zawodowe i wyższe [Department of Higher...]. Edukacja w szkole podstawowej i gimnazjum włącznie jest obowiązkowa. System oświatowy w RPA odgrywa coraz ważniejszą rolę, co potwierdza wzrost wydatków budżetowych. W 2013 roku rząd Republiki Południowej Afryki wydał na edukację $21 \%$ budżetu państwa, w tym $10 \%$ na szkolnictwo wyższe [World Bank, Government..., b.d.].

System finansowania oświaty w RPA jest niewydolny. Państwo zapewnia podstawę programową i finansuje pomieszczenia, ale szkoły muszą się posiłkować czesnym od uczniów (z możliwością zwolnienia) oraz darowiznami. Wielkość dotacji wypłacanej przez rząd jest zależna od poziomu ubóstwa w dzielnicy, w której znajduje się szkoła, stopy bezrobocia i ogólnego poziomu edukacji społeczeństwa. W ostatnich latach ponad $60 \%$ dzieci objęto dofinansowaniem państwa w zakresie czesnego, co pozwoliło najbiedniejszym na podejmowanie nauki zgodnie z posiadanymi zdolnościami.

System szkolnictwa wyższego przeszedł gruntowną reformę w 1994 roku. Zlikwidowano wtedy podziały rasowe i w miejsce poprzednich 36 jednostek utworzono 22 uniwersytety. Uniwersytety i szkoły techniczne nie wyróżniają się na tle światowej konkurencji. Jest to przede wszystkim spowodowane ubytkiem kapitału intelektualnego po 1994 roku.

Ważnym elementem podnoszącym wartość edukacji w RPA jest nauka języka angielskiego, która odbywa się od pierwszej klasy szkoły podstawowej. Umożliwia to włączenie tego kraju w światowe struktury przemysłowe i lokowanie tam produkcji.

Modele oświaty BRICS są zbliżone do europejskich (Tabela 1). Ograniczony jest za to system bezpłatnego szkolnictwa. Wynika to ze zróżnicowanego finansowania i możliwości budżetowych poszczególnych państw. Niemniej wszystkie osiągnęły znaczące sukcesy w zakresie modernizacji edukacji, ograniczając analfabetyzm i podnosząc wskaźniki skolaryzacji.

Pomimo trudnych warunków bytowych wielu społeczeństw, w tym stosunkowo dużego udziału ludności wiejskiej, wszystkie kraje BRICS mogą się pochwalić niskim poziomem analfabetyzmu. W wyniku analizy stwierdzono, że najwyższą dbałość o jakość edukacji podstawowej i średniej prezentują Rosja i Chiny, a najniższą Indie. Natomiast wszystkie państwa skupiają się przede wszystkim na szkolnictwie wyższym.

Kolejnym elementem wymagającym analizy jest finansowanie edukacji w BRICS. Konkurencyjność poszczególnych gospodarek w dużym stopniu zależy od systemów kształcenia, a przede wszystkim inwestycji w szkolnictwie wyższym. 
Tabela 1

Wybrane dane społeczno-ekonomiczne dla BRICS

\begin{tabular}{|c|c|c|c|c|c|c|c|c|}
\hline 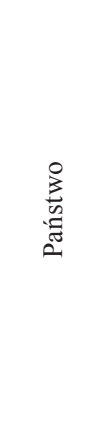 & 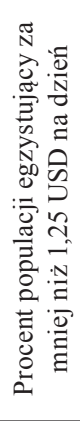 & 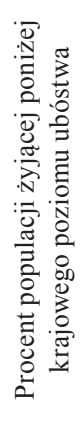 & 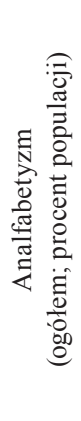 & 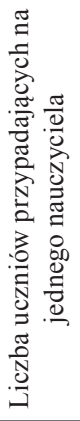 & 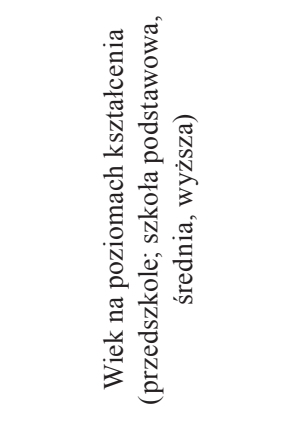 & 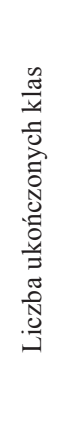 & 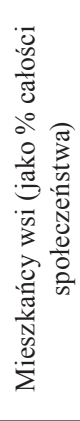 & 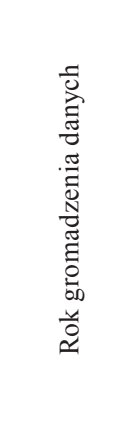 \\
\hline Brazylia & 6 & 21 & 7,4 & 25 & $4-5 ; 6-10 ; 11-17 ; 18-22$ & -- & 15 & 2012-2014 \\
\hline Rosja & 0 & - & 0,3 & 18 & $3-6 ; 7-10 ; 11-17 ; 18-22$ & 14,7 & 26 & 2009-2014 \\
\hline Indie & 32 & 22 & 28,8 & 36 & $3-5 ; 6-10 ; 11-17 ; 18-22$ & 11,9 & 68 & 2006-2014 \\
\hline Chiny & 12 & - & 3,6 & 20 & $4-6 ; 7-11 ; 12-17 ; 18-22$ & 13,2 & 48 & 2009-2014 \\
\hline RPA & 14 & 23 & 5,7 & 27 & $6 ; 7-13 ; 14-18 ; 19-23$ & 13,6 & 38 & 2012-2014 \\
\hline
\end{tabular}

Żródło: opracowane własne na podstawie: UNDP, Internation Human Development Indicators, https://data.undp.org/dataset/Table-6-Multidimensional-Poverty-Index/frx9-rb5i [dostęp: 28.10.2015], oraz World Bank, statistics data, http://data.worldbank.org/ [dostęp: 28.10.2015], oraz CIA, Country Comparison to the World of Literacy Rate, The World Factbook 2015, https:// www.cia.gov/library/publications/the-world-factbook/fields/2103.html\#136 [dostęp: 03.11.2015].

\section{Finansowanie edukacji a konkurencyjność w BRICS}

Zmieniające się warunki gospodarcze w ostatnich dekadach XX i na początku XXI wieku, m.in. wyższa integracja państw BRICS z rynkiem światowym oraz postępująca globalizacja, przyspieszyły wzrost tych gospodarek. Lepsza sytuacja gospodarcza zapewniła finansowanie m.in. edukacji. Zakładano, że do utrzymania wzrostu gospodarczego i rozwoju niezbędny jest wysoki poziom wykształcenia społeczeństwa.

W Tabeli 2 zaprezentowano nakłady na edukację na przestrzeni ostatnich 10 lat zarówno w stosunku do PKB kraju, budżetu, jak i w podziale na etapy nauki. Niestety część z państw BRICS nie prowadzi polityki informacyjnej w tym zakresie, więc dane są niekompletne. Pozwalają jednak wnioskować odnośnie do trendów w zakresie finansowania edukacji.

Wydatki na edukację w BRICS rosną. Długookresowy wzrostowy trend występuje zarówno w przypadku udziału w PKB, jak i w ramach budżetu krajowego. W każdym przypadku najwięcej otrzymuje szkolnictwo wyższe. 
Przyjęta w Brazylii reguła wydatkowania co najmniej 5\% PKB na edukację i dystrybuowania środków poprzez władze samorządowe umożliwiła zmniejszenie analfabetyzmu. Pomimo spowolnienia koniunktury w pierwszej dekadzie XX wieku zwiększono udział wydatków na edukację. Niestety jakość kształcenia placówek jest bardzo różna. Pośrednio wynika to z dotacji państwowych, które pokrywają ok. 25-30\% potrzeb. Kształcenie absolwentów i prace badawcze są prowadzone na wyselekcjonowanych uniwersytetach federalnych i w sieci federalnych instytutów badawczych [Schwartzman, 2012, s. 5].

Rosjanie procentowo mniej inwestują w edukację, jednak struktura wydatków ma charakter celowy, w przeciwieństwie do Brazylii. Rosję, jako jedyną z państw BRICS, cechuje lepszy bazowy poziom oświaty. Wydatki są ukierunkowywane przede wszystkim na szkolnictwo wyższe i obowiązkowy okres nauki. Pozostałe poziomy są niedoinwestowane.

Indie istotnie zwiększyły nakłady na edukację, niemniej bardzo duża liczba ludności objęta obowiązkowym kształceniem ogranicza efektywność systemu. Jednoprocentowy wzrost $\mathrm{w}$ ciągu ostatnich 10 lat i pięcioprocentowy pod względem ogółu wydatków wydaje się za niski. Wybrane jednostki naukowe decydują o sile gospodarki. Przeważnie są one finansowane przez międzynarodowe korporacje. Zbyt niskie wydatki w obowiązkowym cyklu kształcenia prowadzą do nadmiernego obciążania klas oraz zatrudniania nauczycieli o niskich kwalifikacjach.

Zaangażowanie Chin w edukację trudno jest oceniać ze względu na problem $\mathrm{z}$ dostępnością danych. $Z$ tego powodu trudno wnioskować o całym systemie, który charakteryzuje silne zróżnicowanie geograficznie. Ostatnie dostępne dane pochodzą z 1999 roku - 1,9\% PKB. W 2015 roku jest to najprawdopodobniej znacznie więcej ze względu na przyspieszony wzrost. Jakość szkolnictwa wyższego potwierdza te przypuszczenia - największe chińskie uczelnie plasują się wysoko w rankingach, a Chiny są najchętniej wybieranym wśród azjatyckich studentów krajem.

RPA od wielu lat inwestuje w edukację. Jest to wynik wieloletnich kontaktów z kulturą europejską. Niestety występuje nierównowaga systemu oświaty: w biedniejszych regionach szkoły są mocno przeciążone uczniami, a w bogatszych, pomimo ograniczonych dotacji, uzyskują silne zewnętrzne wsparcie finansowe, notując dobre wyniki. Szkolnictwo wyższe nie wyróżnia się na tle państw świata, jest jednak najlepsze w regionie. Wzrost wydatków na edukację jest przede wszystkim wynikiem uwolnienia i reformy zapoczątkowanej wraz z odejściem od apartheidu. Wzrost liczby najmłodszych obywateli objętych obowiązkową edukacją mocno nadwyręża system oświaty.

Wydatki państw BRICS na oświatę jako procent PKB są zbliżone do państw rozwiniętych. Luka edukacyjna społeczeństwa jest jednak jeszcze stosunkowo duża. Wszystkie z państw (oprócz Rosji) przed 20 laty miały wskaźniki skolaryzacji na poziomie od 40 do $60 \%$. W 2014 roku było to od 90 do $95 \%$ [OECD, Education..., b.d.]. Nastąpiła więc wyraźna poprawa, przynajmniej na poziomie uczestnictwa społeczeństwa w edukacji. Edukacja, ze względu na swoją specyfikę, wymaga jednak podejścia długookresowego. Najszybciej widoczne zmiany i najsilniej wpływające na potencjał postrzegany na zewnątrz występują w szkolnictwie wyższym. 
$\frac{\sqrt{\frac{\pi}{0}}}{\frac{\pi}{0}}$

\begin{tabular}{|c|c|c|c|c|c|c|c|c|c|c|c|c|}
\hline$\stackrel{m}{\stackrel{\sim}{\circ}}$ & نْ & فं & ن. & ن. & فं & ن. & نْ & فْ & ن. & ن. & ن. & ن. \\
\hline$\frac{\mathfrak{D}}{\stackrel{2}{2}}$ & ?ִ & $\begin{array}{l}\stackrel{b}{u} \\
\ddot{n}\end{array}$ & $\begin{array}{l}\text { तે } \\
\text { ๙ે }\end{array}$ & \begin{tabular}{l}
0 \\
$\ddot{n}$ \\
\multirow{n}{n}{} \\
$m$
\end{tabular} & $\begin{array}{l}n \\
\frac{\sim}{7}\end{array}$ & فْ & فْذَ & ف물 & فِّن & فं & ले & $\stackrel{\overbrace{}}{ \pm}$ \\
\hline$\overline{\bar{D}}$ & 7 & $\stackrel{n}{n}$ & $\frac{\text { के }}{\text { के }}$ & $\begin{array}{l}\text { ㄱ. } \\
\text { ते }\end{array}$ & 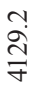 & ن. & فْ & فن & ف물 & فن & ले & $\stackrel{\sim}{ \pm}$ \\
\hline$\stackrel{\circ}{\stackrel{ }{ }}$ & $\begin{array}{l}\infty \\
i\end{array}$ & $\begin{array}{l}b \\
\dot{I}\end{array}$ & $\begin{array}{l}\hat{\partial} \\
\text { ळे } \\
\text { ( }\end{array}$ & $\begin{array}{l}+ \\
\text { ஸे } \\
\text { ণ }\end{array}$ & $\frac{n}{\tilde{m}}$ & فْ & فْذْ & فं & فُ0ْ & فن & m? & $\Xi$ \\
\hline ᄋి & $\underset{i}{b}$ & $\stackrel{\check{I}}{\dot{I}}$ & 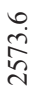 & 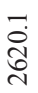 & 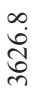 & ن. & فْ & ف물 & ف물 & فن & ஸे & $\stackrel{\infty}{\circ}$ \\
\hline$\stackrel{\infty}{\circ}$ & $\stackrel{+}{\dot{n}}$ & $\exists$ & $\begin{array}{l}n \\
\stackrel{\infty}{N} \\
\stackrel{n}{N}\end{array}$ & $\begin{array}{l}n \\
\stackrel{n}{\circ} \\
\stackrel{n}{n}\end{array}$ & $\begin{array}{l}m \\
\dot{H} \\
m\end{array}$ & F & $\simeq$ & فن & فْ & $\begin{array}{l}0 \\
\infty \\
\infty \\
\infty \\
\infty\end{array}$ & فن & فْ \\
\hline
\end{tabular}

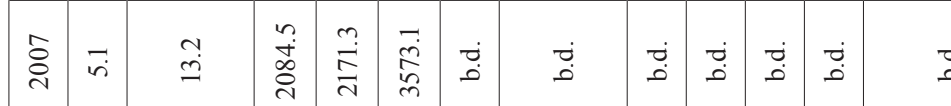

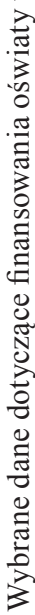

\begin{tabular}{|c|c|c|c|c|c|c|c|c|c|c|c|c|}
\hline $\begin{array}{l}\text { ¿ } \\
\stackrel{\leftrightarrow}{1}\end{array}$ & in & 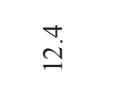 & فํ. & فتِّ & فَّ & ले & $\stackrel{さ}{\stackrel{ \pm}{ \pm}}$ & نَّ & 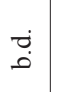 & $\begin{array}{l}n \\
\stackrel{2}{2} \\
\text { مै }\end{array}$ & $\bar{m}$ & $\stackrel{\infty}{=}$ \\
\hline 弚 & $\stackrel{n}{+}$ & $\stackrel{\text { ? }}{=}$ & $\begin{array}{l}\text { ?ִ } \\
\text { तु }\end{array}$ & $\begin{array}{l}\infty \\
\dot{0} \\
\infty \\
ٍ \\
=\end{array}$ & $\begin{array}{l}\hat{~} \\
\text { ò } \\
\text { d }\end{array}$ & $\stackrel{\infty}{m}$ & $\simeq$ & فㄹ. & ف리 & $\begin{array}{l}\infty \\
\stackrel{\circ}{\circ} \\
\stackrel{+}{ \pm}\end{array}$ & $\vec{m}$ & $\stackrel{n}{=}$ \\
\hline 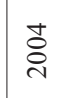 & $\nabla$ & $\stackrel{+}{\circ}$ & 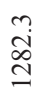 & 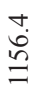 & $\underset{n}{\stackrel{n}{\curvearrowright}}$ & $m$ & $\stackrel{\sim}{=}$ & ذُذّ & فُ & $\stackrel{\mathfrak{m}}{ٍ}$ & $\stackrel{m}{m}$ & $\stackrel{6}{=}$ \\
\hline & 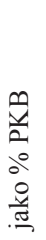 & 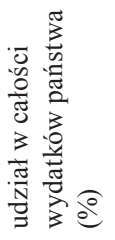 & 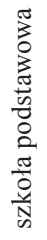 & 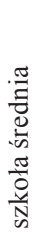 & 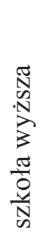 & $\begin{array}{l}\frac{a}{a} \\
\frac{a}{0} \\
\stackrel{0}{0} \\
\frac{\partial}{\sigma}\end{array}$ & 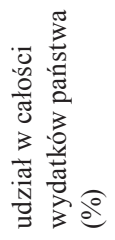 & 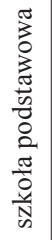 & 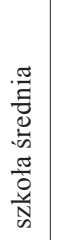 & 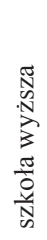 & 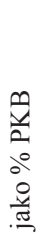 & 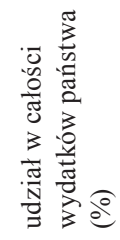 \\
\hline & & & & 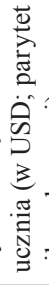 & & & & & 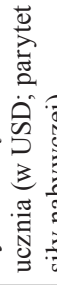 & & & \\
\hline & \multicolumn{5}{|c|}{ VITXZVYG } & \multicolumn{5}{|c|}{ VISOY } & \multicolumn{2}{|r|}{ BIGNI } \\
\hline
\end{tabular}


गुं
ì
$\frac{\pi}{0}$
$\frac{\pi}{\pi}$

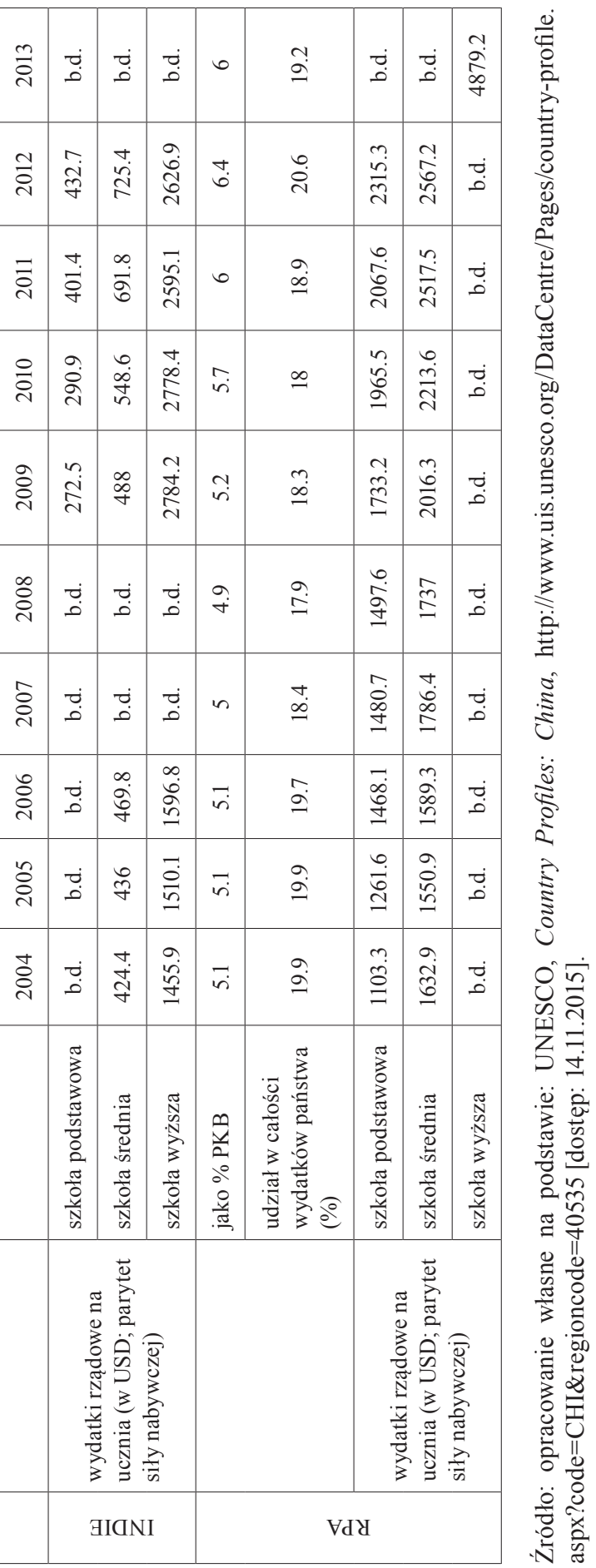




\section{Międzynarodowa pozycja czołowych uniwersytetów BRICS}

Czynnikami, które pobudzają zainteresowanie danym rynkiem, są: szkolnictwo wyższe wraz ze sferą badawczą. Osiągnięcia naukowe zachęcają do lokowania zaawansowanej produkcji w takiej gospodarce.

Społeczeństwa BRICS są mocno zróżnicowane pod względem edukacji. Pierwsza rzecz: w latach 1990-2013 najmocniej wskaźnik skolaryzacji dla szkół wyższych zmienił się w Brazylii, Indiach i Chinach. Należy jednak zauważyć, że zmiana wynikała przede wszystkim z niskich wartości początkowych oscylujących w granicach 10\% (np. w Chinach obecnie jest to ok. 30\%). W Rosji zmiana wynosiła zaledwie $5 \%$, ale obecny poziom oscyluje w granicach $75 \%$ [UNESCO, Country profiles..., b.d.]. Druga kwestia to zróżnicowana jakość edukacji. Trzecia to wielkość rynku pracy. Należy zauważyć, że wskaźnik skolaryzacji $30 \%$ w przypadku Chin to liczebnie znacznie więcej kapitału ludzkiego niż 75\% w Rosji. Jest to więc miara niewłaściwa do oceny potencjału konkurencyjnego. Lepiej jest porównywać konkurencyjność postrzeganą m.in. poprzez rankingi, które uwzględniają odczucia inwestorów i perspektywiczne podejście do rynku.

Times Higher Education World University Ranking pozycjonuje międzynarodowe jednostki naukowe według ich misji, tj. dydaktycznej, naukowej, transferu wiedzy oraz perspektywy międzynarodowej (postrzegania). Uczelnie otrzymują punkty za: jakość nauki, mierzoną między innymi kadrą, cytowania publikacji naukowych $\mathrm{z}$ afiliacją jednostki, prowadzone badania, międzynarodowość oraz związki z przemysłem wyrażone np. patentami [„,The Times”, b.d.]. Po uwzględnieniu wag powstaje klasyfikacja (Tabela 3). Z państw BRICS najlepsze wyniki mają chińskie uniwersytety, a dalej te zlokalizowane w RPA i Rosji.

Tabela 3

„Times Higher Education: University Ranking” (Ranking uczelni wyższych „Timesa”; wybrane uczelnie wyższe w BRICS)

\begin{tabular}{|l|l|c|c|c|c|c|}
\hline \multicolumn{1}{|c|}{ Kraj } & \multicolumn{1}{|c|}{ Nazwa uczelni wyższej } & 2012 & 2013 & 2014 & 2015 & 2016 \\
\hline BRAZYLIA & University of São Paulo & 178 & 158 & 226 & 219 & 287 \\
\hline \multirow{2}{*}{ ROSJA } & Lomonosow Moscow State University & 282 & 211 & 238 & 196 & 161 \\
\hline \multirow{2}{*}{ INDIE } & Indian Institute of Science & NWR & NWR & NWR & 286 & 256 \\
\cline { 2 - 7 } & Indian Institute of Technology in Delhi & NWR & NWR & 387 & NWR & 436 \\
\hline \multirow{2}{*}{ CHINY } & Peking University & 49 & 46 & 45 & 48 & 42 \\
\cline { 2 - 7 } & Tsinghua University & 71 & 52 & 50 & 49 & 47 \\
\hline \multirow{2}{*}{ RPA } & University of Cape Town & 103 & 113 & 126 & 124 & 120 \\
\hline
\end{tabular}

* NWR - nie występuje w rankingu

Źródło: opracowanie własne na podstawie: „Times Higher Education: University Ranking 2012-2016", https://www.timeshighereducation.com/ [dostęp: 12.11.2015]. 
Drugi ranking (Tabela 4) przedstawia zestawienie przygotowane przez Center for World University Rankings. Poza pozycjami występującymi w innych rankingach, decydujące znaczenie mają losy absolwentów oraz jakość edukacji (łącznie odpowiadają za $50 \%$ oceny).

Tabela 4 „University Ranking 2015: CWUR” (Ranking uczelni wyższych z 2015 r. Center for World University; wybrane uczelnie wyższe w BRICS)

\begin{tabular}{|c|c|c|c|c|c|c|c|c|c|c|c|c|}
\hline 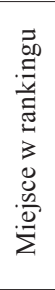 & 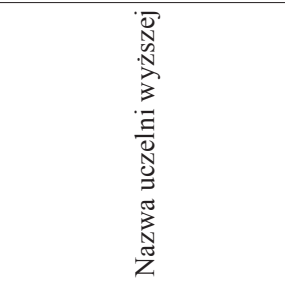 & 苛 & 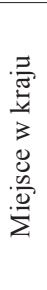 & 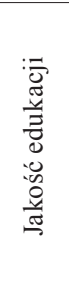 & 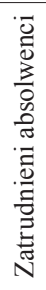 & 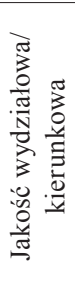 & 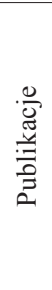 & 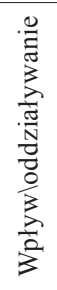 & 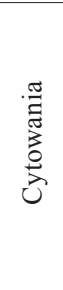 & 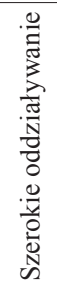 & 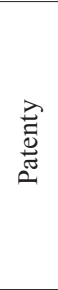 & 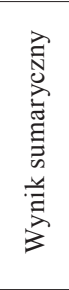 \\
\hline 56 & Peking University & China & 1 & 182 & 38 & $218+$ & 52 & 131 & 182 & 125 & 20 & 54.26 \\
\hline 59 & $\begin{array}{l}\text { Lomonosov Moscow } \\
\text { State University }\end{array}$ & Russia & 1 & 14 & 175 & 48 & 268 & 254 & 287 & 344 & 861 & 54.19 \\
\hline 132 & University of São Paulo & Brazil & 1 & 297 & 71 & $218+$ & 59 & 186 & 136 & 164 & 710 & 49.31 \\
\hline 149 & $\begin{array}{l}\text { University } \\
\text { of the Witwatersrand }\end{array}$ & $\begin{array}{l}\text { South } \\
\text { Africa }\end{array}$ & 1 & 61 & 32 & 172 & 442 & 237 & 321 & 447 & 291 & 48.75 \\
\hline 341 & $\begin{array}{l}\text { Indian Institute } \\
\text { of Technology Delhi }\end{array}$ & India & 1 & $367+$ & 59 & $218+$ & 635 & 943 & $812+$ & 781 & 625 & 45.54 \\
\hline
\end{tabular}

Źródło: opracowanie własne na podstawie: CWUR 2015, http://cwur.org/2015/ [dostęp: 12.11.2015].

Ranking ten przedstawia najlepsze uczelnie z poszczególnych państw BRICS. Wyróżniają się szczególnie chińskie (pod względem patentów, publikacji, liczby zatrudnionych absolwentów) i rosyjskie (pod względem jakości kształcenia, jakości kierunków). W przypadku tych dwóch państw można więc uznać, że nakłady ponoszone na edukację przyniosły oczekiwane rezultaty. Powinno to przełożyć się na wysoką pozycję tych państw w rankingach konkurencyjności, a przynajmniej w kategoriach odpowiedzialnych za edukację i innowacyjność.

\section{Edukacja w rankingach konkurencyjności - BRICS}

Do pomiaru związku edukacji i konkurencyjności przyjęto ranking prezentowany przez Światowe Forum Ekonomiczne. Ze względu na metodologię dane obejmują okres od 2011 do 2015 roku. Wybrane kategorie dotyczą edukacji wyższej, rynku pracy i innowacji. Niższa wartość oznacza wyższe miejsce w rankingu (Tabela 5). 
Tabela 5

Wybrane kategorie z rankingu „Global Competitiveness Report” opracowywanego przez World Economic Forum (lata 2011-2015)

\begin{tabular}{|c|c|c|c|c|c|c|c|c|c|c|c|c|}
\hline & \multicolumn{3}{|c|}{ 2011-2012 } & \multicolumn{3}{|c|}{ 2012-2013 } & \multicolumn{3}{|c|}{ 2013-2014 } & \multicolumn{3}{|c|}{ 2014-2015 } \\
\hline & 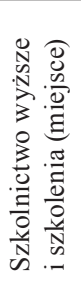 & 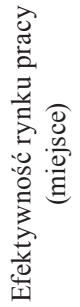 & 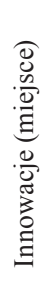 & 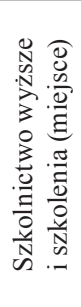 & 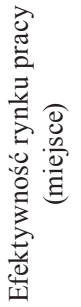 & 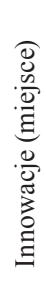 & 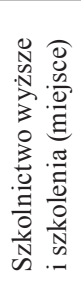 & 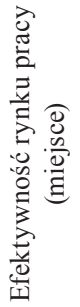 & 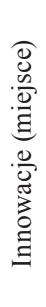 & 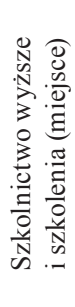 & 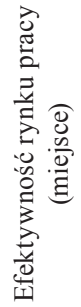 & 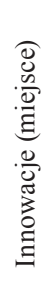 \\
\hline 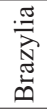 & 57 & 83 & 44 & 66 & 69 & 49 & 72 & 92 & 55 & 41 & 109 & 62 \\
\hline $\begin{array}{l}\frac{\pi}{2} \\
\stackrel{2}{\alpha}\end{array}$ & 52 & 65 & 71 & 52 & 84 & 85 & 47 & 72 & 78 & 39 & 45 & 65 \\
\hline$\stackrel{\cong}{\Xi}$ & 87 & 81 & 38 & 86 & 82 & 41 & 91 & 99 & 41 & 93 & 112 & 49 \\
\hline 坣 & 58 & 36 & 29 & 62 & 41 & 33 & 70 & 34 & 32 & 65 & 37 & 32 \\
\hline$\underset{\Omega}{\widetilde{a}}$ & 73 & 95 & 41 & 84 & 113 & 42 & 89 & 116 & 39 & 86 & 113 & 43 \\
\hline
\end{tabular}

Źródło: opracowanie własne na podstawie: „Global Competitiveness Report 2011-2015”, http://www.weforum.org/reports [dostęp: 17.11.2015].

Najkorzystniejsze przeobrażenia (ocena reform szkolnictwa wyższego) przeszły Brazylia, Rosja i Chiny. Szczególnie silne zmiany zachodzą w Brazylii, ponieważ eliminowane są podmioty, które cechuje niska jakość. Pozostałe są łączone celem wytworzenia niezbędnej masy potencjału pozwalającego na rywalizację z najlepszymi uczelniami na świecie. Uczelnie zlokalizowane w RPA, Chinach i Indiach dobrze wypadają w przypadku innowacyjności. Tempo wdrażania i rozwijania rozwiązań jest bardzo szybkie, co przekłada się na ich dobrą pozycję w rankingach. Najwyżej zostały sklasyfikowane rynki pracowników w Rosji i Chinach, co wynika ze zróżnicowania wykształcenia oraz specjalizacji.

Nakłady finansowe skierowane na edukację pozwalają utrzymać dotychczasowy potencjał, co jest ważne dla dalszego rozwoju. Raporty konkurencyjności potwierdzają tę prawidłowość.

\section{Podsumowanie}

Wszystkie z państw BRICS podejmują kroki na rzecz poprawiania i rozwijania edukacji. Sprawna oświata jest niezbędnym elementem dalszego rozwoju. Rezultaty bieżącej polityki edukacyjnej będą jednak widoczne dopiero za około dwie 
dekady, kiedy obecni sześciolatkowie zasilą rynek pracy. Wtedy będzie można stwierdzić, czy podejmowane kroki były należyte i które z państw najlepiej wykorzystało okres prosperity.

Reformowanie systemów oświaty, przebiegające od drugiej połowy XX wieku, umożliwiło włączenie gospodarek BRICS do globalnego rynku pracy i produkcji. Bez standaryzacji edukacji, m.in. poprzez stworzenie systemów oświaty na podstawie międzynarodowych sprawdzonych rozwiązań, niemożliwym byłoby właściwe wykorzystanie tak bogatych w kapitał ludzki rynków pracy. Niemniej nadal występują w nich ułomności, które muszą zostać wyeliminowane w najbliższej dekadzie, aby możliwy był dalszy rozwój.

W najtrudniejszej sytuacji pozostają Indie, które ze względu na znaczny przyrost populacji nie są w stanie zapewnić należytych warunków bytowych, nie mówiąc już o edukacji. Jednak i tam obserwowane są olbrzymie postępy, szczególnie w zakresie walki z analfabetyzmem oraz wdrażaniem równego dostępu kobiet i mężczyzn do edukacji.

Z BRICS najwyżej należy ocenić szkolnictwo wyższe w Chinach i Rosji. Oba państwa bardzo dużo inwestują w rozwój najlepszych ośrodków badawczych, co potwierdzają międzynarodowe rankingi i osiągnięcia naukowe. Brazylia i RPA angażują się w poprawę systemu oświaty, jednak brakuje im długofalowej strategii i obowiązkowości.

Przekrojowe dane z „Global Competitiveness Report” potwierdzają dotychczasową słabość systemów oświaty i wspierania nauki w badanej grupie państw. Pomimo coraz większych nakładów nie zmieniają pozycji, a w niektórych kategoriach nieznacznie tracą w stosunku do innych państw.

Konkurencyjność BRICS zależy od subiektywnych odczuć inwestorów i międzynarodowej atmosfery odnośnie do wzrostu poszczególnych gospodarek oraz zmian na ich rynkach pracy. Nieodzowna jest tutaj rola władz, które powinny dostosowywać ofertę kształcenia i jej zakres do zmieniających się warunków zarówno w kraju, jak i na świecie. Tylko w ten sposób możliwe będzie utrzymanie zainteresowania inwestorów państwami BRICS.

\section{Bibliografia}

Bingman Ch.F. (2010), Education: A Comparision of India and China, "Journal of the Washington Institute of China Studies", Fall, Vol. 5, No. 2.

Bittar M.O. (2000), O ensino superior no Brasil e a formação do segmento das Universidades comunitárias, 23 Reunião Anual da ANPED, Caxambu.

Cheney R. (2005), India Education Report, National Center on Education and the Economy, 11, Delhi.

CIA, Country Comparison to the World of Literacy Rate, The World Factbook 2015, https://www. cia.gov/library/publications/the-world-factbook/fields/2103.html\#136 [dostęp: 03.11.2015].

CWUR 2015, http://cwur.org/2015/ [dostęp: 12.11.2015].

Czeladko R., Czas na łączenie wyższych uczelni, http://www4.rp.pl/artykul/126843-Czas-na-laczenie-wyzszych-uczelni.html [dostęp: 14.11.2015]. 
Department of Higher Education and Training of South Africa, http://www.dhet.gov.za/ [dostęp: 10.11.2015].

Department of Higher Education in India, http://mhrd.gov.in/higher_education [dostęp: 24.10.2015].

Dhawan A., Let's start at the very beginning, „Bussines Today”, http://www.businesstoday.in/ magazine/cover-story/focus-school-college-education-for-gdp-growth-ashish-dhawan/ story/213470.html [dostęp: 12.11.2015].

Fan Ch.S., Overland J. (1999), Human Capital, Growth, and Inequality in Russia, ,Journal of Comparative Economics", No. 27, s. 618-643.

Grodzicki J. (2000), Edukacja czynnikiem rozwoju gospodarczego, Wydawnictwo Adam Marszałek, Toruń.

Liberska B. (2013), Nowe centra wzrostu światowej gospodarki, „Economic Studies”, Nr 2 (LLXXVII), Instytut Nauk Ekonomicznych PAN, Warszawa.

Madaan N., Homeschooling too is fine, says Sibal, „Times of India”, http://epaper.timesofindia.com/Default/Scripting/ArticleWin.asp?From=Archive $\&$ Source=Page $\&$ Skin=TOINE W\&BaseHref=TOIPU\%2F2010\%2F09\%2F08\&ViewMode=GIF\&GZ=T\&PageLabel=1\& EntityId=Ar00104\&AppName=1 [dostęp: 21.10.2015].

MEC, Alunos que recebem Bolsa Familia têm melhor desempenho escolar, http://www.brasil. gov.br/educacao/2013/10/alunos-que-recebem-bolsa-familia-tem-melhor-desempenho-escolar [dostęp: 12.11.2015].

Ministério da Educação Brasil, http://www.mec.gov.br/ [dostęp: 11.11.2015].

Ministry of Education and Science of the Russian Federation, http://минобрнауки.рф/ [dostęp: 15.11.2015].

Ministry of Education of the People's Republic of China, http://www.moe.edu.cn/publicfiles/ business/htmlfiles/moe/moe_2792/index.html [dostęp: 04.11.2015].

MOE, National base of Education in PRC, http://www.moe.edu.cn/publicfiles/business/htmlfiles/moe/s8490/index.html [dostęp: 04.11.2015].

National Department of Basic Education in South Africa, http://www.education.gov.za/ [dostęp: 10.11.2015].

Niewiński S., Czy XXI wiek będzie stuleciem Chin?, http://www.polska-azja.pl/2015/06/13/s-niewinski-czy-xxi-w-bedzie-stuleciem-chin-cz-1/ [dostęp: 15.11.2015].

OECD, Education at a Glance 2014, www.oecd.org/edu/Education-at-a-Glance-2014.pdf [dostęp: 10.11.2015].

OECD, Russian Federation - Country Note - Education at a Glance 2013: OECD Indicators, http://www.oecd.org/edu/Russian\%20Federation_EAG2013\%20Country\%20Note. pdf [dostęp: 02.11.2015].

Purohit B.C. (2014), Efficiency of Social Sector Expenditure in India, Routledge, New York.

Schwartzman S. (2012), Economic development and higher education policy in Brazil, „International Higher Education", $\mathrm{Nr} 67$.

Soboleva I. (2011), Patterns of Human Capital Development in Russia: Meeting the Challenge of Market Reforms and Globalization, „International Journal of Institutions and Economies", Vol. 3, No. 2.

Stańko A. (2009), Poziom wydatków na edukację w krajach członkowskich Unii Europejskiej, „Ekonomika i Organizacja Gospodarki Żywnościowej”, Nr 73, Zeszyty Naukowe SGGW, Warszawa. 
The Constitution of India, online: http:/lawmin.nic.in/olwing/coi/coi-english/coi-indexenglish.htm [dostęp: 16.11.2015].

„The Economist”, Economist Intelligence Unit, http:/www.eiu.com/home.aspx [dostęp: 02.11.2015].

„The Times”, Times Higher Education: University Ranking 2012-2016, https://www.timeshighereducation.com/world-university-rankings/2016/world-ranking\#!/page/0/ length/25 [dostęp: 16.11.2015].

Tsang M.C. (1996), Financial Reform of Basic Education in China, „Economics of Education Review", Vol. 15, No. 4.

UNDP, Internation Human Development Indicators, https://data.undp.org/dataset/Table-6-Multidimensional-Poverty-Index/frx9-rb5i [dostęp: 28.10.2015].

UNESCO, Country Profiles: China, http://www.uis.unesco.org/DataCentre/Pages/country-profile.aspx?code $=$ CHI\&regioncode $=40535$ [dostęp: 14.11.2015].

UNESCO, Education for all by 2015, http://www.unesco.org/new/en/education/themes/leading-the-international-agenda/education-for-all/the-efa-movement/ [dostęp: 03.11.2015].

UNESCO-IBE (2011), World Data on Education, VII Ed. 2010/11, Brazil, Geneva.

UNESCO, International Literacy Statistics: A review of concepts, http://www.uis.unesco.org/ Library/Pages/default.aspx [dostęp: 20.10.2015].

Velkoff V.A. (1998), Women's education in India, „Women of the World”, WID/98-1.

WEF, Global Competitiveness Report 2011-2015, http:/www.weforum.org/reports [dostęp: 17.11.2015].

World Bank, Goverment expediture on education: SA, http://data.worldbank.org/indicator/ SE.XPD.TOTL.GB.ZS [dostęp: 11.11.2015].

World Bank, statistics data, http://data.worldbank.org/ [dostęp: 28.10.2015].

World Data on Education: Seventh editon 2010-11, http://www.ibe.unesco.org/en/document/ vorld-data-education-seventh-edition-2020-11, [dostęp: 03.11.2015].

Yang C., Gale T. (2003), Policy Analysis: On Chinese Higher Education Entry Policy, Monash University, Clayton.

Zhang Y. (2003), Private Education in China: Issues and Prospects, „Perspectives”, Vol. 4, No. 4. 